\title{
Economics
}

\section{The Effect of Covid-19 on Unemployment and Price Changes in Ethiopia: Evidence from Woldia Town "Does the Downward Sloping Philips Curve Hold True"}

\author{
Tadesse Wudu Abate \\ Department of Economics, Faculty of Business and Economics, Woldia University, Woldia, Ethiopia
}

Email address:

tade.wudu22@gmail.com

\section{To cite this article:}

Tadesse Wudu Abate. The Effect of Covid-19 on Unemployment and Price Changes in Ethiopia: Evidence from Woldia Town "Does the Downward Sloping Philips Curve Hold True”. Economics. Vol. 9, No. 4, 2020, pp. 73-78. doi: 10.11648/j.eco.20200904.11

Received: October 9, 2020; Accepted: October 26, 2020; Published: November 23, 2020

\begin{abstract}
The massive spread of corona creates pressure on the general systems of the world countries. As stated in some studies corona virus affect every institution and individuals of the world in many aspects. Specifically it results in high unemployment, low level of production and significance rise in the nominal price of commodities. This study tries to explain the change in those economic variables to analyze the effect of Covid-19 on the living standard of households in Woldia town, Amhara regional state of Ethiopia using a data obtained from the north wollo zone planning commission which had been collected from sampled individuals monthly. Since the issue is so recent and absence of many conducted researches on this area, this article have no specific chapter for review of literature and gives more focus for data analysis part. Then descriptive analysis indicates the presence of valuable rise in unemployment and average price levels simultaneously and the OLS regression result disproved the applicability of Philips curve for the study area under the influence of COVID-19. While it emerged from animal hosts, currently COVID-19 continues to spread across the globe through human-to-human contact. It resulted in many socio economy impacts on the world society and deteriorates their day to day activities. Unemployment is the major manifestation of COVID-19 due quarantine requirement designed to control the spread of the virus and this indirectly creates high level of increments in the average price of consumer necessity goods. As per the descriptive and econometric analysis of this study there is high unemployment and rise in average price at a time opposed to the assumption of Philips curve.
\end{abstract}

Keywords: COVID-19, Philips Curve, Regression Analysis, Unemployment, Woldia Town, Ethiopia

\section{Introduction and Overview}

Coronavirus (a pandemic comes next to Spanish flue) can be considered as a respiratory disorder which quickly spreads from person to person when individuals by any means touch the infected persons of any other objects contaminated with the virus. It had been caused by the SARS-CoV-2 virus and it belongs to the identical family of coronaviruses that caused the Severe Acute Respiratory Syndrome outbreak in 2003 and therefore the Middle East Respiratory Syndrome outbreak in 2012 [3]. This pandemic was reported in early January 2019 in Wuhan city in Hubei province of People's Republic of China. While it emerged from animal hosts, currently COVID-19 continues to spread across the globe through human-to-human contact. Additionally to the adverse effects on health and human life's, pandemics will affect the economic activity. But, the impact of the virus on economics activities of world population might not be long- lasting if the underlying cause is contained quickly [12]. For instance, one in every of the largest pandemic within the modern history was the Spanish Flu of 1918-1919. At the time, the planet couldn't easily control the pandemics. Thus, additionally to the deep health crisis and deaths of individual the planet economy also collapsed [7]. Many service based businesses suffered double -digit losses. Just like the previous pandemics, coronavirus crisis is first and foremost a public health threat, but it's also, and increasingly, an economic threat. Besides its worrying effects on human life, the novel strain of coronavirus (COVID-19) has the potential to significantly slowdown not only the Chinese economy but also the worldwide economy [11]. When it involves the economic shocks, it's important to differentiate three sources - two of which are tangible. First 
are the purely medical shocks workers in their sickbeds aren't producing GDP. Second is that the economic impact of public and personal containment measures things like school and factory closures, travel restrictions, and quarantines. The third is literally 'all in our heads. The full cost of COVID-19 in terms of human lives is yet to unfold. Alongside the value of lives and deep health crisis, the planet is witnessing an economic recession which will severely impact the wellbeing of enormous parts of the population within the years to come back [10].

The COVID-19 pandemic is highly disruptive to development the economy in Africa, no matter the source of resources. From USD 61.5 in December 2019 to USD 23.2 in March 2020, Oil prices had a historic collapse,. This can be a significant blow to a continent whose oil rents represent $4.5 \%$ of GDP (OECD/ATAF/AUC, 2019. It's still too early to assess how large a rebound in prices the assembly cuts agreed by OPEC and Russia in April and also the G-20 energy ministers' agreement will prompt. In general, countries' tax bases have shrunk as domestic industries lose revenue, like African airlines losing USD 4.4 billion in revenue within the first three months of 2020 [14]. China, Africa's main trading partner and one among its biggest sources of investment, saw its Purchasing Managers' index hit a rock bottom, dropping from 50 rights down to 35.6 between January and February. At the identical time, stock exchanges at the tip of February saw their worst week since the 2008-09 stock market crash. The most index of the Egyptian stock market, EGX30, declined by over $30 \%$ between February and end March [6].

Once discovered from china, the Corona virus affects the living standard of citizens in all countries of the world and obliged to change their social, political, economic cultural habits through applying some levels of social distancing measures. Ethiopia as one member of African nations some predictions suggest that Covid-19 will have 2.9 percentage points off the 2020 fiscal year's economic process in Ethiopia even though estimations global estimation suggest that world economy could lose $\$ 2.7$ trillion with this crisis, an amount comparable to the full GDP of UK Projections. In our country Ethiopia this pandemic expansion leads to large number of unemployment when majority of big factories, industrial parks, and service giving organizations became shutdown because of the curfew applied in the country at least for 6 months. Earlier to this study, the international labor organization has predicted that the world unemployment to be raised from low to high stage with estimated number of between 5.3 and 24.7 million [1].

Apart from such gloomy picture of growth in 2019/20, the Ethiopian economy is additionally characterized by significant macroeconomic instability and precarious prices and high levels of unemployment (and hence exchange problem) condition even before the onset of the economic effect of COVID-19. Just to mentions a number of these in figures: general inflation is currently 23 percent, while food inflation being 26 percent; the Birr is devalued by the government significantly from about 32 percent a pair of weeks ago to about 34.34 (more than 7 percent) now; the government debt (without including recent pledges by the donors, which is significant) as percentage of GDP is above 55 percent; the export-import gap remained significant because we are importing quite 5 times our exports which is simply below $\$ 3$ billion once a year. The government also predicted that about 30 million (half of this thanks to COVID effect) people may be food insecure and wish help this year alone. Thus, it's within the context of such precarious condition that the pandemic is hitting the country's economy [4].

Ethiopia has recorded strong economic performance over the preceding years, as reflected by the common real GDP rate of about $10 \%$ once a year. The expansion was expected to sustain a minimum of for the short term, as long as the favorable conditions still support it. Nevertheless, recent reports from both local and international institutions reveals that the past growth remained an unlikely situation thanks to the pandemic affecting several segments of the economy. As per the recent country report of the IMF economy growth will significantly diminish [5]. This report identified two critical effects of the pandemic are underscored: deterioration of prices specifically to be increased more than double and high number of unemployment because of stay at home orders declared by government of nations. Because of the low regulatory protection, the ill-functioning economy and therefore to population scenarios that sustained for over twenty years became more Sevier. So this became a reason for many researches to be conducted around the world to identify the effect of the corona virus on different countries' economies [8]. However, like other business undertakings and economy wide scenario, the world contains a higher chance to be suffering from the COVID 19 unless timely remedial measures are in-placed. This can be because African nations naturally may be a fragile undertaking which is probably going to be littered with the performance of the economy still because the wellbeing their citizens [13].

As stated in the studies corona virus affect every institution and individuals of the world in many aspects. Specifically it results in high unemployment, low level of production and significance rise in the nominal price of commodities [2]. This study tries to explain the change in those economic variables to analyze the effect of Covid-19 on the living standard of households in Woldia town, Amhara regional state of Ethiopia using a data obtained from the north wollo zone planning commission which had been collected from sampled individuals monthly. Since the issue is so recent and absence of many conducted researches on this area, this article have no specific chapter for review of literature and gives more focus for data analysis part.

\section{Material and Method of Analysis}

\subsection{Description of the Study Area}

North Wollo is one of 15 zones of the Amhara Region of northern Ethiopia. It is surrounded by south by South Wollo, on the west by South Gondar, on the north by Wag Hemra, on the northeast by Tigray Region, and on the east by Afar 
Region. Its highest point is Mount Abuna Yosef. Its towns include Lalibela (known for its rock-cut churches) and Woldia. North Wollo acquired its name from the previous province of Wollo [9].

According to North wollo zone planning commissions projection of 2012, this Zone contains a total population of $1,763,245$, of whom 882,537 are men and 880,708 women; with a vicinity of $12,172.50$ square kilometers, North Wollo incorporates a population density of 123.25 . While 155,273 or $10.35 \%$ are urban inhabitants, an additional 2 persons are pastoralists. a complete of 367,343 households were counted during this Zone, which ends in a median of 4.48 persons to a household.

\subsection{Data Type, Sources and Methods of Analysis}

The data used or this study is secondary data collected by planning commission of Trade and industry office of North Wollo zone administration. Then after obtaining the data methodologically more emphasis is given for descriptive method of analysis. The tabular and graphical presentations are applied to observe the change in unemployment and prices of commodities. In addition to those descriptive methods, econometric model specifically simple linear regression had been applied to see the relationship between unemployment and price level as a test or the applicability of downward sloping Philips curve which states the inverse relationship between those two economic variables. There is a need to test this hypothesis since such relationship between inflation and unemployment raise the idea of policy trade off. The Phillips curve rapidly becomes a cornerstone of macroeconomic policy analysis [15]. It suggested that policymakers could choose different combinations of unemployment and inflation rates. That is we could have low unemployment as long as we put up with high inflation. The policy measures to reduce unemployment always lead to higher inflation rate and policy measures which reduce inflation rate always contribute to higher unemployment.

\section{Data Analysis}

\subsection{Descriptive Analysis}

Unemployment status of Woldia Town under Covid-19

Under this part of the study, descriptive summery is more applied to investigate about by what amount the level of unemployment and price have been changed starting from the coming of corona virus until the end of September. So graphical method specifically pied chart is used to observe the recent unemployed individuals to be either from either from public sector, privates sector or self-employment conditions. And the tabular presentation is also applied to show how price level of goods and services had been rise during the time of COVID-19. With this regard the following table presents the level of unemployment in the town.

Table 1. Unemployment due to corona virus.

\begin{tabular}{llllllllll}
\hline \multicolumn{2}{l}{ Sectorial specification } & \multicolumn{2}{l}{ Monthly change in Unemployment } \\
\hline No. & Sectors & March & April & May & June & July & August & September & Total \\
\hline 1. & Service & 10440 & 7538 & 1410 & 4584 & 1300 & 1450 & 850 \\
2. & Industry & 2100 & 1540 & 1564 & 460 & 826 & - & - & - \\
3 & Agriculture & 851 & 225 & 167 & 30 & - & - & - & 127572 \\
\hline
\end{tabular}

\begin{tabular}{|c|c|c|c|}
\hline \multicolumn{2}{|c|}{ Ratio of un employed persons from public, private and self-employments } & \multirow{2}{*}{ Number of unemployed } & \multirow{2}{*}{$\begin{array}{l}\text { Remarks } \\
\text { Ratio }\end{array}$} \\
\hline No. & Areas & & \\
\hline 1. & Private & 16255 & $45.9 \%$ \\
\hline 2. & Public & 8264 & $23.4 \%$ \\
\hline 3. & Self-employed & 10816 & 30.7 \\
\hline Total & & 35335 & $100 \%$ \\
\hline
\end{tabular}

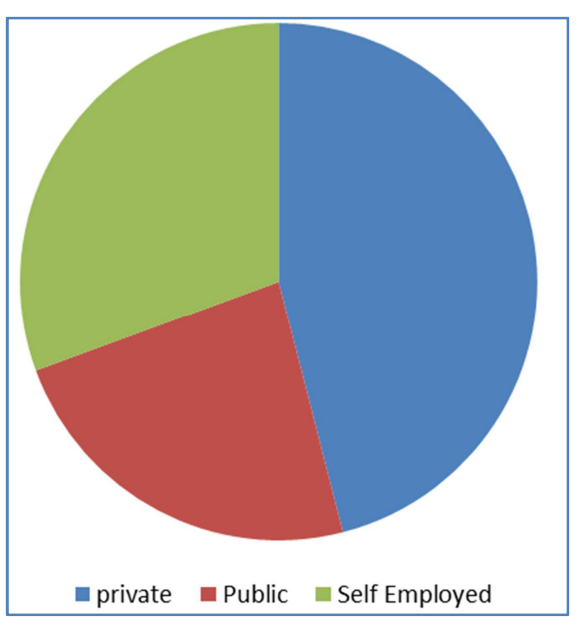

Figure 1. Pie chart for unemployment ration.
The table presented above indicates that majority of unemployment arises from service sector since almost all activities in hotels, restaurants, game zones, and tourism offices seized their normal functioning because of quarantine declared by the government. Additionally those individuals who had been unemployed from the public sector are for temporal time since there is no customer to be served because of the stay at home command.

Again as we can see from the pie chart presented above, the highest proportion of unemployment is arisen from the private sector since the greedy nature of company owners obliged them to fire many of their workers without any compromises and the inability of the government to share the internationally organization financed money for the owner of private companies. Then this high unemployment increment leads to the fail of production in every sector and creates shortage of 
good and service demanded by the society. Then because of this rise in demand in relation to supply shortage and consumers future expectation on availability of commodities, the average price level of the town increased at very significant level. In addition to this, individuals who engaged in self-employment like electronic shops, street vending and petty traders and any consultancy providing individual became obliged to go back to their rural hometown for the sake of sustaining their life.

Rise in Prices of Commodities in Woldia Town

Average prices of selected fruits and vegetables before and after Covid-19.

Table 2. Average price of fruits and vegetables.

\begin{tabular}{|c|c|c|c|c|}
\hline \multicolumn{3}{|c|}{ Before Covid-19 } & \multicolumn{2}{|c|}{ During the first month of Covid-19 period } \\
\hline No. & Items & Unit price/kilo & Unit prices/kilo & Rise in price (\%) \\
\hline 1 & Banana & 35 & 35 & 0 \\
\hline 2 & Orange & 60 & 70 & 16.7 \\
\hline 3 & Tomato & 25 & 40 & 60 \\
\hline 4 & Onion & 20 & 40 & 100 \\
\hline 5 & Potato & 20 & 25 & 25 \\
\hline 6 & Pepper & 60 & 80 & 33.3 \\
\hline 7 & Lemon & 2/unit & 5/unit & 150 \\
\hline 8 & Salad & 8/unit & 15/unit & 87.5 \\
\hline \multicolumn{3}{|c|}{ Average rise in the price of fruits and vegetables } & & 59.1 \\
\hline
\end{tabular}

Individuals are suffering a lot from the effect of the corona virus since the average price of those commodities is rising by more than half. This indicates that dwellers of the town are acting a difficulty of having access to one of the basic needs called food. Since fruits are more important for the healthy functioning our body peoples in this area are said to be incurring the nutrients obtained from fruits and may be faced health distortion when lacking the required vitamins.

Average tariff for transportation from Woldia town to other nearby town.

Table 3. Average transportation tariff.

\begin{tabular}{llllll}
\hline \multicolumn{2}{l}{ Before the occurrence of Covid-19 } & & \multicolumn{4}{l}{ After the occurrence of Covid-19 } \\
\hline No. & Destination & Tariff in Birr & Destination & Tariff in birr & Rise in tariff (\%) \\
\hline 1 & Kobo & 25 & Kobo & 50 & 100 \\
2 & Dessie & 60 & Dessie & 150 & 150 \\
3 & Robit & 20 & Robit & 30 & 50 \\
4 & Mersa & 15 & Mersa & 30 & 50 \\
5 & Sanka & Sanka & 25 & 66.67 \\
\multicolumn{2}{l}{ Aggregate change in tariff (by considering the average value) } & & & 83.34 \\
\hline
\end{tabular}

What we can understand from the above is that individuals of this compound are obliged to pay more than $83 \%$ of the tariff they were paying before the occurrence of the corona virus. This rise in tariff has two implications as an additional challenge for the people. The first one is that individuals involved in petty trades are paying higher amount of transportation cost costs which will minimize the profit level of their exchange and indirectly forced them to increase the price of the commodity they are selling. Secondly, this rise in tariff leaved a restriction on every individual not to travel from place to place even for necessary condition like for getting medication from Hospitals, other religious and social aspects.

Average rise in prices of Cereal Crops and inputs for food preparation.

Table 4. Average price of cereal crops.

\begin{tabular}{llllll}
\hline \multicolumn{2}{l}{ Before the occurrence of Covid-19 } & & \multicolumn{3}{l}{ After the occurrence of Covid-19 } \\
\hline No. & Items & Unit price in Birr/Kilo & Items & Unit price in birr/kilo & \% Rise in price \\
\hline 1 & Wheat & 50 & Wheat & 55 & 10.0 \\
2 & Maize & 28 & Maize & 30 & 7.1 \\
3 & Sorghum & 35 & Sorghum & 43 & 22.9 \\
4 & Bean & 45 & Bean & 40 & -11.1 \\
5 & Teff & 45 & Teff & 52 & 15.6 \\
6 & Barley & 33 & Barley & 35 & 7.06 \\
7 & Raw meat & 280 & Raw meat & 300 & 12.5 \\
8 & Lentil & 80 & Lentil & 90 & 8.33 \\
9 & Pea & 60 & Pea & 65 & 8.57 \\
10 & Food Oil/liter & 350 & Food Oil & 380 & 18.71 \\
\multicolumn{2}{l}{ Average increments in unit price } & & & & \\
\hline
\end{tabular}

The rise in price of cereal crops is low when compared with the change in price o fruits and transportation costs. But still the change is very high since cereal crops are the most important determents of Ethiopian citizens either to fulfill their demand for food or not and their lively hood of to obtain sufficient food or being starved is highly influenced by those commodities. So we can say that peoples who live in Woldia town are highly suffering this rise in price of cereals resulted 
because of the occurrence of Corona virus.

\subsection{Econometric Analysis}

Under this section regression will be conducted to test either the theory Philips curve is applicable or not. Theoretically, this curve is explanation for the presence of inverse relationship between the level of price and unemployment and concludes that that the two economic variables can't simultaneously move in the same direction. But realistic facts on ground under the COVID-19 period indicates that there is high unemployment level because of quarantine and this may leads to low production and thereby high demand for necessity goods with low supply which indirectly leads to rise in average price level.

So, to see the existed relationship between unemployment and price level simple linear regression is specified by letting unemployment the independent variable to affect the average price level in woldia town as measured by consumer price index.

- reg cpi unemploy

\begin{tabular}{r|ccc} 
Source & SS & df & MS \\
\hline $\begin{array}{r}\text { Model } \\
\text { Residual }\end{array}$ & 254.042967 & 1 & 254.042967 \\
\hline Total & 477.374439 & 6 & 79.5624064
\end{tabular}

$\begin{array}{lrr}\text { Number of obs } & = \\ \text { F }(1, \quad 5) & =5.69 \\ \text { Prob }>\text { F } & 0.0628 \\ \text { R-squared } & 0.5322 \\ \text { Adj R-squared } & =0.4386 \\ \text { Root MSE } & 6.6833\end{array}$

\begin{tabular}{|c|c|c|c|c|c|c|}
\hline cpi & Coef. & Std. Err. & t & $P>|t|$ & [95\% Conf. & Interval] \\
\hline unemploy & .0013955 & .0005851 & 2.38 & 0.063 & -.0001087 & .0028996 \\
\hline _cons & 43.62725 & 3.886549 & 11.23 & 0.000 & 33.63656 & 53.61794 \\
\hline
\end{tabular}

Figure 2. OLS estimation result from Stata.

From the regression result estimated using OLS technique of estimation the $\mathrm{R}^{2}$ value is given to be 0.532 to indicate that out of the total change in price, about $53 \%$ is explained by the change in unemployment resulted from quarantine command under corona virus period. This agrees with the previous idea since high unemployment can lead to low production and hence demand pull inflation.

The level of unemployment has significant impact on the rise in price since the $\mathrm{t}$-value for unemployment is greater than two (which is 2.36). This implies that a unit increment in unemployment results in a rise in average price level by 0.0014 amount. From this we can understand that, under the period of COVID-19, there is simultaneous rise of unemployment and average price level and the central assumption of Philips curve is not applicable at least for the study area under consideration.

\section{Conclusion}

Coronavirus can be considered as a respiratory disorder spreads from person to person. It had been caused by the SARS-CoV-2 virus and it belongs to the identical family of coronaviruses that caused the Severe Acute Respiratory Syndrome outbreak in 2003 and therefore the Middle East Respiratory Syndrome outbreak in 2012. This pandemic was reported in early January 2019 in Wuhan city in Hubei province of People's Republic of China. While it emerged from animal hosts, currently COVID-19 continues to spread across the globe through human-to-human contact. It resulted in many socio economy impacts on the world society and deteriorates their day to day activities. Unemployment is the major manifestation of COVID-19 due quarantine requirement designed to control the spread of the virus and this indirectly creates high level of increments in the average price of consumer necessity goods. As per the descriptive and econometric analysis of this study there is high unemployment and rise in average price at a time opposed to the assumption of Philips curve.

\section{References}

[1] Alemayehu Geda (2020). The Macroeconomic and Social Impact of COVID-19 in Ethiopia and Suggested Directions for Policy Response, Addis Ababa University.

[2] Alemayehu Geda (2020). The COVID-19 Damage on the Ethiopian Service Sector: A Supplement Using Google Search Trend "Big data".

[3] Habtamu Legese Feyisa. The World Economy at COVID-19 Quarantine: Contemporary Review. International Journal of Economics, Finance and Management Sciences. Vol. 8, No. 2, 2020, pp. 63-74. doi: 10.11648/j.ijefm.20200802.11.

[4] ILO (2020). COVID-19 and the world of work: Impact and policy responses. ilo.org/global/topics/coronavirus.

[5] IMF Country Report No. 20/150 The Federal Democratic Republic of Ethiopia World Bank, 2020. 
[6] Kibrom Abay, Kibrom Tafere, Andinet Woldemichael (2020, forthcoming). Winners and losers from COVID-19: Global Evidence from Google search Data.

[7] Pesaran, M. H., Shin, Y., Smith, R. J. 2001. Bounds Testing Approaches to the Analysis of Level Relationships, Journal of Applied Econometrics, 16: 289-326.

[8] Tesfaye Boru (2020). The Impact of COVID 19 on the Private Banking System. Working paper on research gate.

[9] Johns Hopkins University Medicine. (2020). Coronavirus Resource Center. https://coronavirus.jhu.edu/.

[10] UNICEF (2020), Ethiopia Socio-economic impacts of COVID-19 Update - 14th May.

[11] World Bank (2020). Managing the impact of COVID-19 on education systems around the world: How countries are preparing, coping, and planning for recovery. World Bank Blogs.

[12] World Health Organization. (2020a). Coronavirus disease (COVID-2019) situation reports. World Health Organization.

[13] U.S. Food and Drug Administration. (2020, March 11). Update information for blood establishments regarding the novel coronavirus outbreak. https://www.fda.gov/vaccines-blood.

[14] European Milk Banking Association. (2020, February 25). COVID-19: EMBA position statement. https://europeanmilkbanking.com/covid-19-emba-position-stat ement/.

[15] Human Milk Banking Association of North America. (2020, March 6). Milk banking and COVID-19. https://www.hmbana.org/news/statement-on-coronavirus.html. 